\title{
ANALISIS PERUBAHAN KEMISKINAN SEKTORAL INDONESIA BERDASARKAN SEKTOR KEGIATAN EKONOMI, PERIODE KEBIJAKAN 2004 - 2017
}

\author{
Ginanjar Syamsuar ${ }^{1}$, Ono Tarsono ${ }^{2}$ \\ Sekolah Tinggi Ilmu Ekonomi Indonesia \\ Jl. Kayu Jati Raya No. 11A, Rawamangun - Jakarta 13220, Indonesia \\ ginanjar.syamsuar@stei.ac.id ${ }^{1)}$,ono_tarsono@yahoo.co.id ${ }^{2)}$
}

\begin{abstract}
Abstrak - Dengan menggunakan data susenas tahun 2004, 2009, 2014, dan 2017, penelitian ini bertujuan untuk menghitung besarnya ukuran kemiskinan agregat dan sektoral selama periode kebijakan pembangunan pada tiga masa pemerintahan Indonesia tahun 2004-2017, serta mengidentifikasi sektor apa saja yang berkontribusi terhadap perubahan kemiskinan agregat di Indonesia. Analisis yang digunakan adalah analisis dekomposisi kemiskinan sektoral. Hasil analisis diperoleh bahwa pada ketiga periode kebijakan terjadi penurunan kemiskinan agregat (P0), sedangkan kedalaman kemiskinan (P1) dan keparahan kemiskinan (P2) penurunan hanya terjadi pada masa kebijakan RPJMN-I dan II akan tetapi pada masa kebijakan RPJMN-III mengalami peningkatan. Pada masa kebijakan RPJMN-I kemiskinan P0 menurun 2.53 dari 16.68 menjadi 14.15 , P1 menurun 0.57 dari 3.06 menjadi 2.49, dan P2 menurun 0.23 dari 0.90 menjadi 0.67 , pada masa kebijakan RPJMN-II kemiskinan P0 menurun 2.9 dari 14.15 menjadi 11.25, P1 menurun 0.74 dari 2.49 menjadi 1.75 , dan P2 menurun 0.23 dari 0.67 menjadi 0.44 . Penyebab terjadinya penurunan kemiskinan agregat P0, P1, dan P2 secara dominan pada RPJMN-I dan RPJMN-II diakibatkan oleh pengaruh intra-sektoral dan antar-sektoral, pada RPJMN-III penurunan kemiskinan agregat P0 diakibatkan oleh pengaruh intrasektoral dan inter-sektoral sedangkan peningkatan P1 dan P2 diakibatkan oleh pengaruh interaksi. Pengentasan kemiskinan pada masa kebijakan RPJMN-I, RPJMN-II dan RPJMN-III penurunan tingkat kemiskinan agregatnya secara signifikan dikontribusi oleh empat sektor lapangan pekerjaan utama yaitu pada RPJMN-I oleh sektor pertanian informal, perdagangan formal/informal, transportasi formal/informal, dan konstruksi formal/informal, pada RPJMN-II oleh sektor pertanian formal, perdagangan formal, transportasi formal/informal, dan keuangan informal, dan pada RPJMN-III oleh sektor pertanian informal, perdagangan formal, transportasi formal/informal, dan keuangan formal/informal.
\end{abstract}

Kata kunci: Dekomposisi, kemiskinan, kedalaman kemiskinan, keparahan kemiskinan, kemiskinan sektoral 


\section{PENDAHULUAN}

Kemiskinan adalah ketidakmampuan rumahtanga atau orang dalam memenuhi kebutuhan hidup layak minimum. Definisi kebutuhan layak minimum dan cara pengukurannya akan menentukan tinggi rendahnya garis kemiskinan. Ukuran kemiskinan yang sering digunakan di berbagai Negara berkembang adalah kemiskinan absolute yang didasarkan pada pengeluaran atau pendapatan untuk hidup layak minimum yang didasarkan pada sejumlah keranjang pangan (food basket) atau pangan minimal untuk memenuhi kebutuhan kalori ditambah sejumlah pengeluaran non pangan yang minimal untuk hidup layak.

Untuk mengukur kemiskinan, BPS menggunakan konsep kemampuan memenuhi kebutuhan dasar (basic needs approach). Dengan pendekatan ini, kemiskinan dipandang sebagai ketidakmampuan dari sisi ekonomi untuk memenuhi kebutuhan dasar makanan dan bukan makanan yang diukur dari sisi pengeluaran.

Sumber penghasilan utama rumah tangga menjadi salah satu indikator tingkat kesejahteraan yang diharapkan dapat mencerminkan kondisi sosial ekonomi suatu rumah tangga. Cerminan tingkat kesejahteraan suatu rumah tangga dapat dilihat dari status miskin atau tidak miskin suatu rumah tangga yang ditentukan dari rata-rata pengeluaran per kapita per bulan suatu rumah tangga.

Pada tahun 1998 BPS melakukan penyempurnaan metode pengukuran kemiskinan rumahtangga, dengan menyempurnakan kerangjang pangan (food basket) dan komponen non pangan, yang didasarkan pada survei terbatas di sepuluh provinsi. Penghitungan garis kemiskinan makanan didasarkan atas kebutuhan energi minimum penduduk Indonesia sebesar 2.100 kilo kalori per hari yang merupakan rekomendasi Widyakarya Pangan dan Gizi tahun 1978. Metode ini menghasilkan perluasan komoditas food basket dan keterbandingan antar daerah, dimana dihasilkan food basket nasional dengan 52 jenis. Juga dilakukan penyempurnaan dalam penentuan garis kemiskinan non-makanan dengan meningkatkan kualitas pelayanan untuk: (1) perawatan kesehatan dari puskesmas ke dokter praktek umum, (2) biaya pendidikan dari tingkat sekolah dasar menjadi tingkat sekolah lanjutan tingkat pertama, dan (3) transportasi dalam kota menjadi transportasi antar kota. Penghitungan garis kemiskinan non-makanan didasarkan pada 51 komoditi yang mencakup perumahan, pakaian dan 
alas kaki, perawatan kesehatan, biaya pendidikan, transportasi serta aneka barang dan jasa lain.

Terkait dengan upaya perencanaan sistem pengendalian pembangunan nasional, fokus masalah kemiskinan perlu mendapat perhatian yang lebih besar dalam rangka sinkronisasi antara perencanaan, monitoring dan evaluasi pelaksanaan pembangunan. Angka kemiskinan telah menjadi informasi strategis karena menjadi acuan pencapaian kinerja pemerintah yang senantiasa selama ini selalu dilaporkan oleh Presiden dalam pidato kenegaraan dalam rangka perayaan kemerdekaan di depan sidang paripurna DPR setiap tanggal 16 Agustus.

Berkaitan dengan itu, Sidang Umum Perserikatan Bangsa-Bangsa (PBB) ke 70 pada bulan September 2015 di New York, Amerika Serikat, menjadi titik sejarah baru dalam pembangunan global. Sebanyak 193 kepala negara dan pemerintahan dunia hadir (termasuk Indonesia didalamnya) untuk menyepakati agenda pembangunan universal baru yang tertuang dalam dokumen berjudul Transforming Our World: the 2030 Agenda for Sustainable Development_-berisi 17 Tujuan dan 169 Sasaran yang berlaku mulai tahun 2016 hingga tahun 2030. Dokumen ini dikenal dengan istilah Sustainable Development Goals atau SDGs.

SDGs merupakan kelanjutan Millennium Development Goals (MDGs) yang disepakati oleh negara anggota PBB pada tahun 2000 dan berakhir pada akhir tahun 2015. Namun keduanya memiliki perbedaan yang mendasar, baik dari segi substansi maupun proses penyusunannya. MDGs yang disepakati lebih dari 15 tahun lalu hanya berisi 8 Tujuan, 21 Sasaran, dan 60 Indikator. Sasarannya hanya bertujuan mengurangi separuh dari tiap-tiap masalah pembangunan yang tertuang dalam tujuan dan sasaran.

Kepala negara dan pemerintahan yang menyepakati SDGs telah meneguhkan komitmen bersama untuk menghapuskan kemiskinan, menghilangkan kelaparan, memperbaiki kualitas kesehatan, meningkatkan pendidikan, dan mengurangi ketimpangan. Agenda pembangunan ini juga menjanjikan semangat bahwa tidak ada seorangpun yang akan ditinggalkan. Dijelaskan bahwa setiap orang dari semua golongan akan ikut melaksanakan dan merasakan manfaat SDGs, dengan memprioritaskan kelompok-kelompok yang paling termarginalkan.

Tujuan pembangunan SDGs ternyata masih sejalan dengan program pembangunan sosial yang dicanangkan pemerintah Indonesia terutama pemberantasan 
kemiskinan dan peningkatan kesejahteraan rakyat seperti yang tertuang dalam Rencana Pembangunan Jangka Menengah Nasional (RPJMN) dan program pembangunan pada periode-periode sebelumnya seperti Program Pembangunan Nasional yaitu Propenas. Oleh karena itu, pemerintah baik di pusat maupun daerah, perlu memahami SDGs dan mengupayakan agar tujuan pembangunan tersebut dapat dicapai.

Berdasarkan uraian konsep, kebijakan, metode pengukuran serta beberapa temuan empiris penelitian tentang kemiskinan sebelumnya maka penelitian ini dilakukan untuk maksud menganalisis perubahan ukuran kemiskinan yang terjadi pada tingkat sektoral kegiatan ekonomi dengan tinjauan lebih terhadap indikator sektor pekerjaan utama yaitu sektor tenaga kerja formal dan informal baik pada 9 sektor lapangan usaha maupun 17 sektor lapangan usaha setelah adanya perubahan tahun dasar 2000 menjadi 2010.

Melalui pendekatan dekomposisi kemiskinan sektoral model Ravalion, pada penelitian ini ukuran kemiskinan didekomposisi sesuai sektoralnya guna mengetahui besarnya perubahan indeks kemiskinan di antara periode kebijakan di Indonesia (Ravalion, 1992). Dimana secara spesifik penelitian ini bertujuan untuk 1) Menghitung dan menganalisis perubahan indeks kemiskinan agregat dan sektoral yang terjadi selama periode kebijakan kemiskinan Indonesia tahun 2004-2017, yaitu perubahan indeks kemiskinan sektoral yang terjadi diantara masing-masing masa kebijakan yang dikaji yaitu masa kebijakan Kabinet Indonesia Bersatu 1 (RPJMN-I 2004-2009), Kabinet Indonesia Bersatu 2 (RPJMN-II 2009-2014), dan Kabinet Kerja (RPJMN-III 20142019), 2) Mengidentifikasi pengaruh yang mengakibatkan terjadinya perubahan (peningkatan atau penurunan) indeks kemiskinan sektoral, dan 3) Menentukan sektor apa saja yang berkontribusi secara signifikan terhadap penurunan atau peningkatan indeks kemiskinan di Indonesia pada setiap periode kebijakan yang sedang dikaji.

\section{KAJIAN LITERATUR}

Kemiskinan seringkali didefinisikan sebagai ketidakcukupan pendapatan dan harta untuk memenuhi kebutuhan-kebutuhan dasar seperti pangan, sandang, perumahan, pendidikan dan kesehatan, yang semuanya berada dalam lingkup dimensi ekonomi. Cakupan kemiskinan absolut adalah penduduk yang tidak mampu mendapatkan sumber daya yang cukup untuk memenuhi kebutuhan dasar. Penduduk ini hidup di bawah tingkat pendapatan riil minimum tertentu atau di bawah garis kemiskinan. Garis 
kemiskinan yang digunakan berbeda untuk tiap negara, tetapi yang umum dijadikan standar adalah berdasarkan ketetapan Bank Dunia (BPS, 2009) yaitu pendapatan perkapita sebesar US\$ 1 atau US\$2 per hari dalam US \$ PPP (Purchasing Power Parity), bukan nilai tukar resmi (exchange rate). Sedangkan Badan Koordinasi Keluarga Berencana Nasional menetapkan kemiskinan berdasarkan kriteria keluarga pra sejahtera (pra KS) dan keluarga sejahtera I (KS I).

Penghitungan tingkat kemiskinan dihadapkan pada dua hal, yaitu pengidentifikasian penduduk miskin dari total penduduk dan menghitung indeks kemiskinan berdasarkan data yang tersedia (Sen, 1979). Head-count ratio sebagai ukuran kasar kemiskinan memenuhi dua aksiom yaitu aksioma monotonisitas dan aksioma transfer. Aksioma monotonisitas yaitu suatu kondisi dimana penurunan pendapatan seseorang yang berada di bawah garis kemiskinan akan meningkatkan ukuran kemiskinan. Aksioma transfer yaitu suatu kondisi dimana transfer pendapatan dari seseorang yang berada di bawah garis kemiskinan ke seseorang yang lebih kaya akan meningkatkan ukuran kemiskinan.

Untuk kondisi Indonesia Biro Pusat Statistik (BPS) menggunakan konsep kemampuan memenuhi kebutuhan dasar (basic needs approach) dalam pengukuran kemiskinannya. Dengan pendekatan ini, kemiskinan dipandang sebagai ketidakmampuan dari sisi ekonomi untuk memenuhi kebutuhan dasar makanan dan bukan makanan yang diukur dari sisi pengeluaran. Penghitungan Garis Kemiskinan dilakukan secara terpisah untuk masing-masing provinsi daerah perkotaan dan perdesaan.

Garis Kemiskinan Makanan (GKM) merupakan nilai pengeluaran kebutuhan minimum makanan yang disetarakan dengan 2100 kilokalori per kapita perhari. Paket komoditi kebutuhan dasar makanan diwakili oleh 52 jenis komoditi (padi-padian, umbiumbian, ikan, daging, telur dan susu, sayuran, kacang-kacangan, buah-buahan, minyak dan lemak, dll). Sedangakan Garis Kemiskinan Non-Makanan (GKNM) adalah kebutuhan minimum untuk perumahan, sandang, pendidikan, dan kesehatan. Paket komoditi kebutuhan dasar non-makanan diwakili oleh 51 jenis komoditi (kelompok pengeluaran) di perkotaan dan 47 jenis komoditi (kelompok pengeluaran) di perdesaan. Selanjutnya hasil dari penjumlahan Garis Kemiskinan Makanan dan Non-Makanan disebut sebagai Garis Kemiskinan (BPS, 2008). 
Indikator kemiskinan yang dihitung oleh BPS selain jumlah dan persentase penduduk miskin, juga digunakan ukuran indeks kedalaman kemiskinan (Poverty Gap Index $-\mathrm{P}_{1}$ ) dan indeks keparahan kemiskinan (Distributionally Sensitive Index $-\mathrm{P}_{2}$ ) yang dirumuskan oleh Foster-Greer-Thorbecke (Foster, et. al., 1984).

Tinjauan terhadap rencana program kebijakan pembangunan era pemerintahan reformasi tiga periode kebelakang (periode tahun 2004-2017) yaitu pada saat 2 kali pemerintahan yang dipimpin oleh Presiden Soesilo Bambang Yudhoyono, dan pemerintahan presiden Joko Widodo, dimana kebijakan tentang kemiskinannya tertuang jelas dalam misi dan visi atau rencana sasaran pada masing-masing arah kebijakan pembangunannya. Ketiga periode kebijakan tersebut adalah periode kabinet Indonesia Bersatu-1 2004-2009 (RPJMN-I), periode kabinet Indonesia Bersatu-2 2009-2014 (RPJMN-II), dan periode kabinet Indonesia Kerja 2014-2017 (RPJMN-III 2014-2019).

Pada periode kebijakan 2004-2009, pelaksanaan pembangunan didasarkan pada Rencana Pembangunan Jangka Menengah Nasional (RPJMN-I) 2004 - 2009 dimana sasaran utama penanggulangan kemiskinan yang ditargetkan adalah menurunnya jumlah penduduk miskin (prosentase penduduk miskin yang berada dibawah garis kemiskinan menjadi 8.2 persen pada 2009) serta terpenuhinya hak-hak dasar masyarakat miskin secara bertahap.

Pada periode kebijakan 2009-2014, pelaksanaan pembangunan didasarkan pada Rencana Pembangunan Jangka Menengah Nasional (RPJMN-II) 2009-2014 dimana sasaran utama penanggulangan kemiskinan yang ditargetkan telah dituangkan dalam sasaran pembangunan kesejahteraan rakyat bidang ekonomi, yang dinyatakan secara jelas dengan angka target tingkat kemiskinan yang ingin dicapai pada akhir tahun 2014 sebesar 8-10 persen, dengan tingkat pengangguran terbuka sebesar 5-6 persen untuk pertumbuhan ekonomi rata-rata 6.3-6.8 persen pertahun.

Dan pada periode kebijakan RPJMN-III 2014-2019, sesuai dengan amanat RPJP 2005-2025 dan mempertimbangkan tingginya tingkat ketimpangan dan pola penurunan tingkat kemiskinan selama ini, permasalahannya, serta tantangan yang akan dihadapi dalam lima tahun mendatang, maka sasaran utama (impact) yang ditetapkan adalah:

1) Menurunnya tingkat kemiskinan pada kisaran $7-8$ persen pada akhir 2019 . 
2) Mengupayakan penurunan tingkat ketimpangan pada akhir tahun 2019 sekitar 0.36, agar pendapatan penduduk 40.0 persen terbawah meningkat, dan beban penduduk miskin berkurang.

Beberapa studi empiris yang menjelaskan hubungan antara kemiskinan baik itu dengan pertumbuhan ekonomi ataupun komposisi pertumbuhan ekonomi sektoral serta dekomposisi dari segi ukuran kemiskinannya yang dikaitkan dengan perubahan struktur ekonomi telah banyak dilakukan oleh para ahli di berbagai negara maupun di Indonesia.

Tingkat kemiskinan suatu negara erat kaitannya dengan dinamika perekonomiannya, baik akibat perubahan struktur perekonomiannya maupun perbedaan tingkat pertumbuhan ekonomi sektoral dan regional.

Ravallion (1990) dan Datt (1998) melakukan studi tentang pengaruh komposisi pertumbuhan ekonomi sektoral dan kondisi awal suatu daerah terhadap pengurangan tingkat kemiskinannya. Demikian pula dengan Huppi dan Ravallion (1990), yang meneliti tentang struktur kemiskinan sektoral pada periode adjustment di Indonesia pada pertengahan tahun 1980-an, mendapatkan bahwa meskipun secara keseluruhan tingkat kemiskinan mengalami penurunan, namun pengaruhnya tidak merata pada lintas regional dan sektoral, di mana pengurangan kemiskinan yang signifikan terutama terjadi pada sektor rural farming.

Sementara itu Friedman (2003), yang melakukan studi tentang respon poverty terhadap pertumbuhan ekonomi di Indonesia, mendapatkan adanya respon yang tinggi. Namun perbedaan antar daerah dalam tingkat kemiskinan tetap ada meskipun telah dilakukan langkah-Iangkah untuk mengontrol tingkat pendapatan pada tingkat provinsi. Terlihat bahwa faktor-faktor lokal memainkan peranan penting terhadap tingkat kemiskinan di suatu daerah.

Sementara, Sri Liliani Suselo dan Tarsidin (2008), memaparkan bahwa pada tingkat nasional dinamika tingkat kemiskinan di Indonesia seringkali tidak sejalan dengan tingkat pertumbuhan ekonomi, terdapat beberapa periode dimana pertumbuhan ekonomi diwarnai dengan peningkatan kemiskinan. Lebih lanjut menyimpulkan bahwa tingkat kemiskinan yang terjadi dalam ruang lingkup sektor yang bersangkutan yang diukur dengan Headcount ratio (HCR) dan Income Gap ratio (IGR) sektoral pada umumnya relatif tinggi. Namun jika diukur dengan $H C R$ tertimbang dan IGR tertimbang terlihat bahwa kemiskinan di sektor pertanian, perkebunan, dan perikanan adalah yang paling tinggi. 


\section{METODE ANALISIS}

Penelitian ini fokus pada lokasi dengan cakupan seluruh wilayah Indonesia (nasional) untuk periode waktu 12 tahun, yang terbagi kedalam tiga periode masa pemerintahan yaitu periode tahun 2004-2009, periode 2009-2014, dan periode 20142019 (tahun 2014 s/d 2017).

Data utama konsumsi rumahtangga melalui Survei Sosial Ekonomi Nasional (Susenas) yang digunakan adalah sebanyak 4 (empat) tahun kegiatan survey yaitu Susenas Kor tahun 2004, Susenas Kor tahun 2009, Susenas Modul tahun 2014, dan Susenas Modul tahun 2017.

Dengan menggunakan bantuan software aplikasi pengolah data Stata, terlebih dahulu kelima dataset Susenas (Susenas 2004, Susenas 2009, Susenas 2014, dan Susenas 2017) dikompilasi dan dilakukan pengolahan menurut sektoral berdasarkan pengelompokan kelas status pekerjaan utama formal dan informal, data output hasil olahan yang ditampilkan adalah data jumlah rumahtangga, besaran rata-rata konsumsi perkapita (rupiah/bulan), dan share populasi per sektor yang disusun menjadi sebuah tabel sebagai gambaran untuk Deskripsi Kemiskinan Sektoral.

Besaran Share populasi untuk setiap kelas status pekerjaan utama (formal/informal) dalam sektornya dihitung dengan banyaknya rumahtangga setiap kelas status pekerjaan utama dibagi dengan total rumahtangga seluruh sektor yang kemudian dikalikan dengan $100 \%$.

Tiga buah ukuran kemiskinan dihitung dengan menggunakan Foster-GreerThorbecke (Foster, et. al., 1984), yaitu indeks kemiskinan (Head Count Index) berasosiasi erat dengan Indeks Kedalaman Kemiskinan (Poverty Gap Index) dan Indeks Keparahan Kemiskinan (Poverty Severity Index) yang menangkap secara sukses aspek yang lebih mendetil mengenai situasi kemiskinan. Indeks kemiskinan $\left(\mathrm{P}_{0}\right)$ mengukur seberapa jauh/luas kemiskinan yang terjadi dibandingkan dengan garis kemiskinannya, Indeks kedalaman kemiskinan $\left(\mathrm{P}_{1}\right)$ mengukur seberapa miskin si miskin tersebut, dan indeks keparahan kemiskinan $\left(\mathrm{P}_{2}\right)$ mengukur parahnya kemiskinan dengan memberi bobot lebih pada yang termiskin dari yang miskin.

Model analisis penelitian perubahan kemiskinan sektoral berdasarkan sektor kegiatan ekonomi (9 sektor) diantara periode pemerintahan yang diteliti secara diagram ditampilkan pada gambar 3.1 sebagai berikut: 


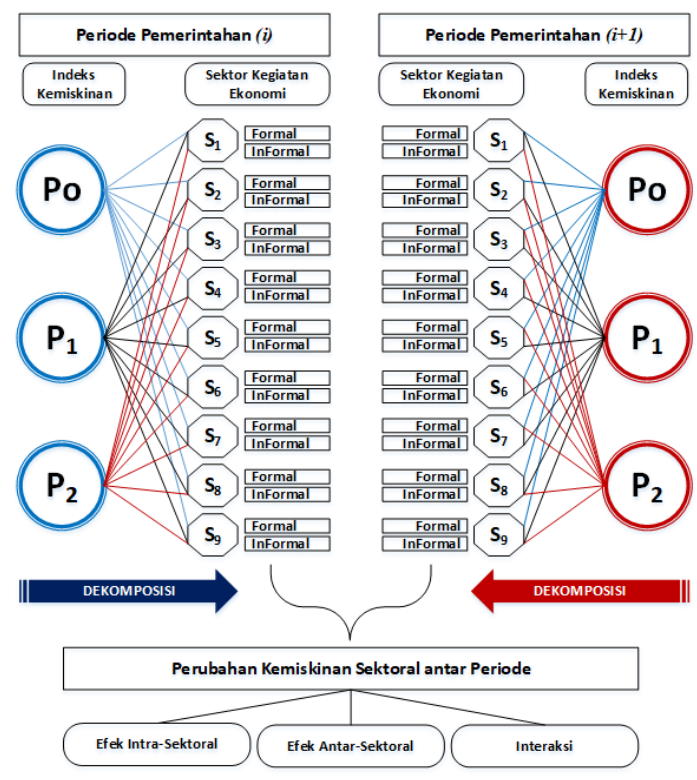

Gambar 3.1. Model Penelitian Perubahan Indeks Kemiskinan Sektoral Indonesia Berdasarkan Sektor Kegiatan Ekonomi.

Selanjutnya untuk menghitung perubahan ketiga indeks kemiskinan tersebut dari setiap masa kebijakan yang akan dihitung perubahannya yaitu "periode akhir Propenas dengan periode akhir RPJMN-I", "periode akhir RPJMN-I dengan periode akhir RPJMN-II", dan "periode akhir RPJMN-II dengan periode akhir RPJMN-III". Maka jumlah kombinasi kemungkinan perubahan indeks kemiskinan akan berjumlah 3 kemungkinan perubahan indeks kemiskinan untuk setiap indeks kemiskinan. Sehingga total keseluruhan perubahan indeks kemiskinan berjumlah $3 \times 3=9$ kemungkinan, yaitu 3 perubahan Head-count Index, 3 perubahan Poverty Gap Index, dan 3 perubahan Poverty Severity Index, secara jelas ditampilkan sebagai berikut:

Perubahan Head-count Index $\left(\Delta P_{0}\right)$ :

$\Delta P_{\text {o(04-09) }}$ : Perubahan Head-count Index antara periode akhir kebijakan Propenas dengan periode akhir kebijakan RPJMN-I

$\Delta P_{\mathrm{O}(09-14)^{x}}$ Perubahan Head-count Index antara periode akhir kebijakan RPJMN-I dengan periode akhir kebijakan RPJMN-II

$\Delta P_{\mathrm{O}(14-17)}:$ Perubahan Head-count Index antara periode akhir kebijakan RPJMNII dengan periode akhir kebijakan RPJMN-III

Perubahan Poverty Gap Index $\left(\Delta P_{1}\right)$ :

$\Delta P_{1(04-09)}:$ Perubahan Poverty Gap Index antara periode akhir kebijakan Propenas dengan periode akhir kebijakan RPJMN-I 
$\Delta P_{1(09-14)}:$ Perubahan Poverty Gap Index antara periode akhir kebijakan RPJMNI dengan periode akhir kebijakan RPJMN-II

$\Delta P_{1(14-17)^{2}}$ Perubahan Poverty Gap Index antara periode akhir kebijakan RPJMNII dengan periode akhir kebijakan RPJMN-III

Perubahan Poverty Severity Index $\left(\Delta P_{2}\right)$ :

$\Delta P_{2(04-09)^{2}}$ Perubahan Poverty Severity Index antara periode akhir kebijakan Propenas dengan periode akhir kebijakan RPJMN-I

$\Delta P_{2(09-14)^{*}}$ Perubahan Poverty Severity Index antara periode akhir kebijakan RPJMN-I dengan periode akhir kebijakan RPJMN-II

$\Delta P_{2(14-17)}:$ Perubahan Poverty Severity Index antara periode akhir kebijakan RPJMN-II dengan periode akhir kebijakan RPJMN-III

Perubahan indeks kemiskinan tersebut dianalisis dan dihitung dengan menggunakan model rumus persamaan (3.1) yaitu Analisis Dekomposisi Sektoral yang diperkenalkan oleh Ravallion dan Huppi (1991) yang ditujukan untuk mengukur kontribusi relatif dari perubahan kemiskinan dalam sektor dan antar-sektoral terhadap perubahan pergeseran penduduk dalam kemiskinan agregat.

Dengan metode analisis ini, indeks kemiskinan agregat didekomposisi atau diurai menjadi indeks kemiskinan sektoral yang terdiri atas 9 sektor dimana setiap sektornya terdiri atas sektor formal dan informal. Adapun perubahan indeks kemiskinan diantara dua periode adalah merupakan hasil akumulasi tiga komponen yaitu (i) intrasektoral, (ii) antar-sektoral, dan (iii) interaksi.

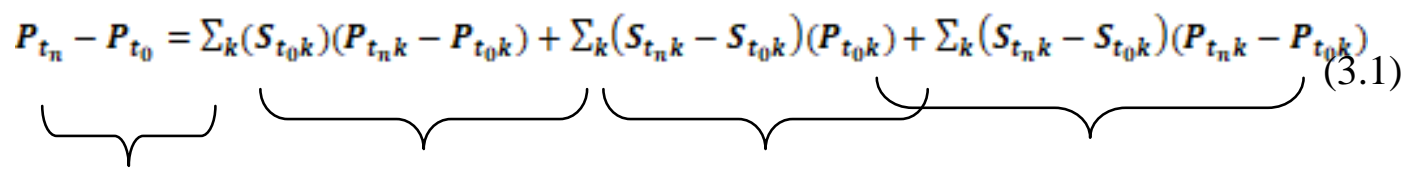

$\begin{array}{lccc}\text { Perubahan } & \text { Komponen } & \text { Komponen } & \text { Komponen } \\ \text { Kemiskinan } & \text { Intra-sektoral } & \text { Antar-sektoral } & \text { Interaksi }\end{array}$

dimana:

$\mathrm{t}_{0}$ adalah tahun awal periode yang digunakan dalam perhitungan (sebagai penunjukan waktu awal dimana capaian prestasi sebelumnya sudah tersedia untuk dibandingkan), 
$\mathrm{t}_{\mathrm{n}}$ adalah tahun akhir periode yang digunakan dalam perhitungan (sebagai penunjukan waktu akhir dimana capaian prestasi yang sedang dievaluasi digunakan sebagai pembanding),

$\mathrm{k}$ adalah sektor kegiatan ekonomi dengan fokus perhatian terhadap indikator ketenagakerjaannya (yaitu formal dan informal) untuk ke-sembilan sektor yang ada secara kegiatan ekonomi di Indonesia,

$\mathrm{P}$ adalah indeks kemiskinan (dimana dalam hal ini adalah merupakan kemiskinan Headcount index $(P o)$, Poverty gap index $\left(P_{1}\right)$, dan Poverty severity index $\left(P_{2}\right)$, dan

$\mathrm{S}$ merupakan share populasi.

Pengertian dan intepretasi dari masing-masing komponen tersebut diatas adalah:

- Komponen Intra-sektoral merupakan perubahan indeks kemiskinan yang diakibatkan oleh perubahan tingkat kemiskinan, dengan asumsi pada tingkat awal share populasi konstan. Dengan kata lain, ini adalah perubahan dalam kemiskinan yang akan terjadi jika share populasi di masing-masing sektor tidak berubah.

- Komponen Antar-sektoral (pergeseran populasi) merupakan perubahan kemiskinan yang diakibatkan oleh perubahan share populasi di masing-masing sektor, dengan asumsi garis kemiskinan dalam sektor konstan. Komponen ini merupakan perubahan kemiskinan yang dihasilkan dari akibat pergeseran individu dari salah satu sektor yang kurang mampu memberikan harapan dari segi pendapatan (miskin) ke sektor yang mampu memberikan harapan peningkatan pendapatan (kaya) atau sebaliknya.

- Komponen Interaksi merupakan perubahan kemiskinan yang disebabkan oleh kedua perubahan dalam share populasi dan tingkat kemiskinan di sektor. Komponen ini dapat "diartikan sebagai ukuran korelasi antara komponen antarsektoral dan komponen intra-sektoral" (Ravallion dan Huppi, 1991).

Jika rumah tangga memperoleh pendapatan yang berasal lebih dari satu sektor kerja (misalnya pertanian, industri, jasa), maka penentuan rumah tangga ke sektor tunggal seringkali membutuhkan suatu analis untuk membuat beberapa keputusan yang tepat tentang bagaimana hal ini harus dilakukan. Dalam kebanyakan kasus, sektor yang dapat menghasilkan pendapatan yang paling besar bagi rumah tangganya sering ditetapkan sebagai rumah tangga. 
Karena ukuran kemiskinan diestimasi berdasarkan pengamatan sampel, kita perlu menguji apakah perbedaan yang diamati untuk setiap nilainya secara statistik signifikan atau tidak (Kakwani, 1990). Pengujian signifikansi perbedaan ukuran kemiskinan diantara dua periode digunakan dengan uji statistic Kakwani (Kakwani Statistic test - $\eta$ ):

$$
\eta=\frac{\widehat{\boldsymbol{P}}_{1}^{*}-\widehat{\boldsymbol{P}}_{2}^{*}}{S E\left(\widehat{\boldsymbol{P}}_{1}^{*}-\widehat{\boldsymbol{P}}_{2}^{*}\right)}
$$

akan mengikuti distribusi normal asimtotik dengan mean nol dan varians satu. Dengan demikian, $\boldsymbol{\eta}$ dapat digunakan untuk menguji hipotesis nol yang menyatakan bahwa perbedaan angka kemiskinan tersebut secara statistik signifikan. 


\section{HASIL ANALISIS DAN PEMBAHASAN}

Analisis perubahan ukuran kemiskinan menggunakan metode analisis dekomposisi sektoral Ravallion (1990), yaitu perubahan ukuran kemiskinan didekomposisi atau diurai menjadi tiga komponen: (i) intra-sektoral, (ii) antar-sektoral, dan (iii) interaksi.

Hasil analisis sesuai masa periode kebijakan yang diteliti yaitu masa periode kebijakan 2004-2009 (RPJMN-I), periode kebijakan 2009-2014 (RPJMN-II), dan periode kebijakan 2014-2017 (RPJMN-III) diperoleh sebagai berikut:

\subsection{Perubahan Ukuran Kemiskinan Periode Kebijakan 2004-2009}

Perubahan ukuran kemiskinan yang terjadi pada periode 2004-2009, untuk ukuran Indeks Kemiskinan (Headcount Index) secara agregat (nasional) mengalami penurunan angka indeks kemiskinan sebesar 2.5355 (dari 16.6808 menjadi 14.1454). Jika diidentifikasi terhadap pengaruh komponen intra-sektoral, antar-sektoral, dan interaksi diantara keduanya teridentifikasi bahwa penurunan ukuran kemiskinan agregat tersebut lebih besar diakibatkan oleh komponen intra-sektoral dan antar-sektoral dengan nilai persentasi perubahannya masing-masing sebesar 85.16 persen dan 20.43 persen dengan besaran perubahan angka kemiskinannya masing-masing sebesar -2.1593 untuk komponen intra-sektoral dan -0.5174 untuk komponen antar-sektoral, dengan kata lain bahwa sebesar 85.16 persen diakibatkan oleh perubahan tingkat kemiskinan pada sektornya dan sebesar 20.43 persen diakibatkan oleh adanya pergeseran individu diantara sektor-sektornya. Sedangkan interaksi diantara komponen intra-sektoral dan antar-sektoralnya mengakibatkan prningkatan angka indeks kemiskinan agregat sebesar 0.1417 dengan persentase pengaruh peningkatannya sebesar minus 5.59 persen. Jika ditinjau dari besaran angka indeks kemiskinan sektoralnya, teridentifikasi bahwa semua sektor yang signifikan perubahanya menunjukan penurunan angka indeks kemiskinan yaitu sektor pertanian informal, sektor konstruksi formal dan informal, sektor perdagangan formal dan informal, sektor transportasi formal dan informal, dan sektor lainnya dengan total persentase perubahannya sebesar 84.2244 persen.

Perubahan ukuran Indeks Kedalaman Kemiskinan (Poverty Gap Index) yang terjadi pada periode 2004-2009, secara agregat mengalami penurunan angka indeks kedalaman kemiskinan sebesar 0.5771 (dari 3.0620 menjadi 2.4848). Jika diidentifikasi 
terhadap pengaruh komponen intra-sektoral, antar-sektoral, dan interaksi diantara keduanya teridentifikasi bahwa penurunan ukuran kedalaman kemiskinan agregat tersebut lebih besar diakibatkan oleh komponen intra-sektoral dan antar-sektoralnya dengan nilai persentasi perubahannya masing-masing sebesar 87.39 persen dan 18.49 persen serta besaran perubahan ukuran kedalaman kemiskinannya sebesar - 0.5044 untuk komponen intra-sektoral dan -0.1067 untuk komponen antar-sektoral, dengan kata lain bahwa sebesar 87.39 persen diakibatkan oleh perubahan tingkat kedalaman kemiskinan pada sektornya dan sebesar 18.49 persen diakibatkan oleh adanya pergeseran individu diantara sektor-sektornya. Sementara komponen interaksi diantara komponen intrasektoral dengan antar-sektoral mengakibatkan peningkatan angka indeks kedalaman kemiskinan agregat sebesar 0.0340 dengan persentase peningkatannya sebesar minus 5.88 persen. Jika ditinjau menurut sektoralnya, teridentifikasi bahwa 6 sektor mengalami penurunan angka indeks kedalaman kemiskinan yang signifikan yaitu sektor listrik informal, sektor konstruksi formal, sektor perdagangan formal dan informal, sektor transportasi formal dan informal, sektor jasa formal, dan sektor lainnya. Sementara satu sektor signifikan mengalami peningkatan angka indeks kedalaman kemiskinan yaitu sektor keuangan formal dan informal.

Untuk ukuran Indeks Keparahan Kemiskinan (Poverty Severity Index) secara agregat mengalami penurunan angka indeks keparahan kemiskinan sebesar 0.2287 (dari 0.8993 menjadi 0.6706). Jika diidentifikasi terhadap pengaruh komponen intra-sektoral, antar-sektoral, dan interaksi diantara keduanya teridentifikasi bahwa penurunan ukuran keparahan kemiskinan agregat tersebut lebih besar diakibatkan oleh komponen intrasektoral dan antar-sektoralnya dengan nilai persentase perubahannya masing-masing sebesar 90.88 persen dan 14.71 persen dengan besaran perubahan angka keparahan kemiskinannya masing-masing sebesar minus 2.2078 untuk komponen intar-sektoral dan minus 0.0336 untuk komponen antar-sektoral, dengan kata lain bahwa sebesar 90.88 persen diakibatkan oleh perubahan tingkat keparahan kemiskinan pada sektornya dan sebesar 14.71 persen diakibatkan oleh adanya pergeseran individu diantara sektorsektornya. Sementara komponen interaksi diantara komponen intra-sektoral dan antarsektoral mengakibatkan peningkatan angka indeks keparahan kemiskinan agregat sebesar 0.0128 dengan persentase pengaruh peningkatannya sebesar minus 5.59 persen. Jika ditinjau menurut sektoralnya, teridentifikasi bahwa 8 sektor mengalami penurunan 
angka indeks keparahan kemiskinan yang yaitu sektor pertanian formal, sektor pertambangan formal, sektor listrik informal, sektor konstruksi formal, sektor perdagangan formal dan informal, sektor transportasi formal dan informal, sektor jasa formal, dan sektor lainnya), sementara satu sektor signifikan mengalami peningkatan angka indeks keparahan kemiskinan yaitu sektor keuangan informal.

Secara total pada masa periode kebijakan RPJMN-I 2004-2009 terjadi penurunan ukuran kemiskinan agregat baik untuk indeks kemiskinan (P0) menurun sebesar 2.5355 dari 16.6808 menjadi 14.1454, indeks kedalaman kemiskinan (P1) menurun sebesar 0.5771 dari 3.0620 menjadi 2.4848, maupun indeks keparahan kemiskinan (P2) menurun sebesar 0.2287 dari 0.8993 menjadi 0.6706. Penyebab terjadinya penurunan ukuran kemiskinan agregat tersebut teridentifikasi secara dominan disebabkan oleh adanya pengaruh perubahan ukuran kemiskinan pada intra-sektoral dan antar-sektoral yaitu dengan persentase perubahan total pengaruh intra-sektoral sebesar $116.67 \%$ untuk P0, $116.27 \%$ untuk P1, dan $116.77 \%$ untuk P2, sementara persentase perubahan pengaruh antar-sektoral sebesar $20.43 \%$ untuk P0, $18.49 \%$ untuk P1, dan $14.71 \%$ untuk P2. Walaupun secara total (agregat) indeks kemiskinannya turun akan tetapi teridentifikasi beberapa sektor yaitu sektor pertambangan informal, sektor keuangan formal dan informal besaran indeks kemiskinannya meningkat, hal ini memberikan arti bahwa sektor-sektor tersebut tidak berhasil dalam pengentasan kemiskinan. Dan sektor-sektor yang berkontribusi secara signifikan terhadap penurunan ukuran kemiskinan agregat P0 adalah sektor pertanian informal, konstruksi, perdagangan, transportasi, dan sektor lainnya. P1 dikontribusi oleh sektor listrik informal, konstruksi formal, perdagangan, transportasi, keuangan, jasa formal, dan sektor lainnya. Sementara P2 dikontribusi oleh sektor pertanian formal, pertambangan formal, listrik informal, konstruksi formal, perdagangan, transportasi, keuangan informal, jasa formal, dan sektor lainnya.

\subsection{Perubahan Ukuran Kemiskinan Periode Kebijakan 2009 - 2014}

Perubahan ukuran kemiskinan yang terjadi pada periode 2009-2014, untuk ukuran Indeks Kemiskinan (Headcount Index) secara agregat (nasional) mengalami penurunan angka kemiskinan sebesar 2.8990 (dari 14.1454 menjadi 11.2464). Jika diidentifikasi terhadap pengaruh komponen intra-sektoral, antar-sektoral, dan interaksi 
diantara keduanya teridentifikasi bahwa penurunan ukuran kemiskinan agregat tersebut lebih besar diakibatkan oleh komponen intra-sektoral dan antar-sektoralnya dengan nilai persentasi perubahannya masing-masing sebesar 58.75 persen dan 64.36 persen dengan besaran perubahan ukuran kemiskinannya masing-masing sebesar -1.7032 untuk komponen intra-sektoral dan -1.8657 untuk komponen antar-sektoral, dengan kata lain bahwa sebesar 58.75 persen diakibatkan oleh perubahan tingkat kemiskinan pada sektornya dan sebesar 64.36 persen diakibatkan oleh adanya pergeseran individu diantara sektor-sektornya. Sementara komponen interaksi diantara komponen intrasektoral dan antar-sektoralnya mengakibatkan peningkatan ukuran indeks kemiskinan agregat sebesar 0.6699 dengan persentase pengaruh peningkatannya sebesar minus 23.11 persen. Jika ditinjau menurut sektoralnya, teridentifikasi bahwa tiga sektor mengalami penurunan angka indeks kemiskinan yang signifikan yaitu sektor pertanian formal, sektor keuangan formal dan informal, dan sektor lainnya, sementara dua sektor signifikan mengalami peningkatan angka indeks kemiskinan yaitu sektor perdagangan formal, sektor transportasi formal dan informal.

Perubahan ukuran ukuran Kedalaman Kemiskinan (Poverty Gap Index) yang terjadi pada periode 2009-2014, secara agregat (nasional) pada Tabel 4.9 mengalami penurunan angka ukuran kedalaman kemiskinan sebesar 0.7316 (dari 2.4848 menjadi 1.7532). Jika diidentifikasi terhadap pengaruh komponen intra-sektoral, antar-sektoral, dan interaksi diantara keduanya teridentifikasi bahwa penurunan ukuran kedalaman kemiskinan agregat tersebut lebih besar diakibatkan oleh pengaruh komponen intrasektoral dan antar-sektoralnya dengan persentasi perubahannya masing-masing sebesar 68.07 persen (perubahan ukuran indeks kedalaman kemiskinannya -0.4980) dan 41.63 persen (perubahan ukuran indeks kedalaman kemiskinannya -0.3046), dengan kata lain bahwa sebesar 68.07 persen diakibatkan oleh perubahan tingkat kedalaman kemiskinan pada sektornya dan sebesar 41.63 persen diakibatkan oleh adanya pergeseran individu diantara sektor-sektornya. Sementara pengaruh komponen interaksi diantara komponen intra-sektoral dan antar-sektoralnya mengakibatkan peningkatan ukuran indeks kedalaman kemiskinan agregat dengan persentase pengaruh peningkatannya sebesar minus 9.70 persen. Jika ditinjau menurut sektoralnya, teridentifikasi bahwa empat sektor mengalami penurunan angka indeks kedalaman kemiskinan yang signifikan yaitu sektor pertanian formal, sektor pertambangan informal, sektor keuangan formal dan 
informal, dan sektor lainnya, sementara dua sektor signifikan mengalami peningkatan angka indeks kedalaman kemiskinan yaitu sektor perdagangan formal, sektor transportasi informal.

Perubahan ukuran Keparahan Kemiskinan (Poverty Severity Index) yang terjadi pada periode 2009-2014, secara agregat mengalami penurunan angka indeks keparahan kemiskinan sebesar 0.2290 (dari 0.6706 menjadi 0.4416). Jika diidentifikasi terhadap pengaruh komponen intra-sektoral, antar-sektoral, dan interaksi diantara keduanya teridentifikasi bahwa penurunan ukuran keparahan kemiskinan agregat tersebut lebih besar diakibatkan oleh komponen intra-sektoral dan antar-sektoralnya dengan nilai persentasi perubahannya masing-masing sebesar 68.60 persen dan 25.15 persen dengan besaran perubahan ukuran keparahan kemiskinannya masing-masing sebesar -0.1571 untuk komponen intra-sektoral dan -0.0576 untuk komponen antar-sektoral, dengan kata lain bahwa sebesar 68.60 persen diakibatkan oleh perubahan tingkat keparahan kemiskinan pada sektornya dan sebesar 25.15 persen diakibatkan oleh adanya pergeseran individu diantara sektor-sektornya. Sementara pengaruh komponen interaksi diantara komponen intra-sektoral dengan antar-sektoralnya mengakibatkan peningkatan ukuran indeks keparahan kemiskinan agregat dengan persentase pengaruh peningkatannya sebesar 6.24 persen. Jika ditinjau menurut sektoralnya, teridentifikasi bahwa empat sektor mengalami penurunan angka indeks keparahan kemiskinan yang signifikan yaitu sektor pertambangan informal, sektor keuangan formal dan informal, sektor jasa informal, dan sektor lainnya, sementara dua sektor signifikan mengalami peningkatan angka indeks keparahan kemiskinan yaitu sektor perdagangan formal, sektor transportasi informal.

Secara total pada masa periode kebijakan RPJMN-II 2009-2014, terjadi penurunan ukuran kemiskinan agregat baik untuk indeks kemiskinan (P0) yaitu menurun sebesar 2.8890 dari 14.1454 menjadi 11.2464, indeks kedalaman kemiskinan (P1) menurun sebesar 0.7316 dari 2.4848 menjadi 1.7532, maupun indeks keparahan kemiskinan (P2) menurun sebesar 0.2290 dari 0.6706 menjadi 0.4416. Penyebab terjadinya penurunan ukuran kemiskinan agregat tersebut teridentifikasi secara dominan disebabkan oleh adanya pengaruh perubahan ukuran kemiskinan pada intra-sektoral dan antar-sektoral yaitu dengan persentase perubahan total pengaruh intra-sektoral sebesar $58.75 \%$ untuk P0, $68.07 \%$ untuk P1, dan $68.60 \%$ untuk P2, sementara persentase 
perubahan pengaruh antar-sektoral sebesar $64.36 \%$ untuk P0, $41.63 \%$ untuk P1, dan $25.15 \%$ untuk P2. Walaupun secara total (agregat) indeks kemiskinannya turun akan tetapi teridentifikasi beberapa sektor yaitu sektor pertanian informal, sektor industri formal dan informal, sektor listrik formal dan informal, sektor konstruksi formal dan informal, sektor perdagangan formal, dan sektor transportasi formal dan informal besaran indeks kemiskinannya meningkat dari tahun 2009 ke tahun 2014, hal ini memberikan arti bahwa sektor-sektor tersebut tidak berhasil dalam pengentasan kemiskinan. Dan Sektor-sektor yang berkontribusi secara signifikan terhadap penurunan ukuran kemiskinan agregat P0 adalah sektor pertanian formal, perdagangan formal, transportasi, sektor keuangan, dan sektor lainnya. P1 dikontribusi oleh sektor pertanian formal, sektor pertambangan informal, sektor perdagangan formal, sektor transportasi informal, sektor keuangan formal dan informal, dan sektor lainnya. Sementara P2 dikontribusi oleh sektor pertambangan informal, sektor perdagangan formal, sektor transportasi informal, sektor keuangan formal dan informal, sektor jasa informal, dan sektor lainnya.

\subsection{Perubahan Ukuran Kemiskinan Periode Kebijakan 2014- 2017}

Perubahan ukuran kemiskinan yang terjadi pada periode 2014-2017, untuk ukuran Indeks Kemiskinan (Headcount Index) secara agregat mengalami penurunan angka indeks kemiskinan sebesar 0.6043 (dari 11.2464 menjadi 10.6421). Jika diidentifikasi terhadap pengaruh komponen intra-sektoral, antar-sektoral, dan interaksi diantara keduanya teridentifikasi bahwa penurunan ukuran kemiskinan agregat tersebut lebih besar diakibatkan oleh komponen intra-sektoral dan antar-sektoralnya dengan nilai persentasi perubahannya masing-masing sebesar 68.18 persen dan 67.14 persen dengan besaran perubahan ukuran kemiskinannya masing-masing sebesar -0.4120 untuk komponen intra-sektoral dan -0.4057 untuk komponen antar-sektoral, dengan kata lain bahwa sebesar 68.18 persen diakibatkan oleh perubahan tingkat kemiskinan pada sektornya dan sebesar 67.14 persen diakibatkan oleh adanya pergeseran individu diantara sektor-sektornya. Sementara komponen interaksi diantara komponen intrasektoral dan antar-sektoralnya mengakibatkan peningkatan ukuran indeks kemiskinan agregat dengan persentase pengaruh peningkatannya sebesar minus 35.32 persen. Jika ditinjau menurut sektoralnya, teridentifikasi bahwa tiga sektor mengalami penurunan angka indeks kemiskinan yang signifikan yaitu sektor pertanian formal, sektor keuangan 
formal dan informal, dan sektor lainnya, sementara dua sektor signifikan mengalami peningkatan angka indeks kemiskinan yaitu sektor perdagangan formal, sektor transportasi formal dan informal.

Perubahan ukuran Indeks Kedalaman Kemiskinan (Poverty Gap Index) yang terjadi pada periode 2014-2017, secara agregat (nasional) mengalami peningkatan angka indeks kedalaman kemiskinan sebesar 0.0780 (dari 1.7532 menjadi 1.8312). Jika diidentifikasi terhadap pengaruh komponen intra-sektoral, antar-sektoral, dan interaksi diantara keduanya teridentifikasi bahwa peningkatan ukuran kedalaman kemiskinan agregat tersebut lebih besar diakibatkan oleh pengaruh komponen antar-sektoral dan interaksi dengan persentasi perubahannya masing-masing sebesar 31.54 persen (perubahan ukuran indeks kedalaman kemiskinannya 0.0246) dan 75.13 persen (perubahan ukuran indeks kedalaman kemiskinannya -0.0586), dengan kata lain bahwa sebesar 31.54 persen diakibatkan oleh perubahan tingkat kedalaman kemiskinan diakibatkan oleh adanya pergeseran individu diantara sektor-sektornya dan sebesar 75.13 persen diakibatkan oleh adanya pengaruh komponen interaksi diantara komponen intra-sektoral dan antar-sektoralnya. Sementara pengaruh komponen intra-sektoral mengakibatkan penurunan ukuran indeks kedalaman kemiskinan agregat dengan persentase pengaruh peningkatannya sebesar minus 6.67 persen. Jika ditinjau menurut sektoralnya, teridentifikasi bahwa empat sektor mengalami penurunan angka indeks kedalaman kemiskinan yang signifikan yaitu sektor pertanian formal, sektor pertambangan informal, sektor keuangan formal dan informal, dan sektor lainnya, sementara dua sektor signifikan mengalami peningkatan angka indeks kedalaman kemiskinan yaitu sektor perdagangan formal, sektor transportasi informal.

Perubahan ukuran Keparahan Kemiskinan (Poverty Severity Index) yang terjadi pada periode 2014-2017, secara agregat mengalami peningkatan angka ukuran keparahan kemiskinan sebesar 0.0426 (dari 0.4416 menjadi 0.4842). Jika diidentifikasi terhadap pengaruh komponen intra-sektoral, antar-sektoral, dan interaksi diantara keduanya teridentifikasi bahwa peningkatan ukuran keparahan kemiskinan agregat tersebut lebih besar diakibatkan oleh komponen antar-sektoral dan interaksi dengan nilai persentasi perubahannya masing-masing sebesar 41.31 persen dan 62.44 persen dengan besaran perubahan ukuran keparahan kemiskinannya masing-masing sebesar 0.0176 untuk komponen antar-sektoral dan 0.0266 untuk komponen interaksi, dengan kata lain 
bahwa sebesar 41.31 persen diakibatkan oleh perubahan tingkat keparahan kemiskinan antar sektornya dan sebesar 62.44 persen diakibatkan oleh pengaruh komponen interaksi diantara komponen intra-sektoral dengan antar-sektoralnya. Sementara pengaruh komponen intra-sektoral mengakibatkan penurunan ukuran indeks keparahan kemiskinan agregat dengan persentase pengaruh peningkatannya sebesar minus 3.76 persen. Jika ditinjau menurut sektoralnya, teridentifikasi bahwa empat sektor mengalami penurunan angka indeks keparahan kemiskinan yang signifikan yaitu sektor pertambangan informal, sektor keuangan formal dan informal, sektor jasa informal, dan sektor lainnya, sementara dua sektor signifikan mengalami peningkatan angka indeks keparahan kemiskinan yaitu sektor perdagangan formal, sektor transportasi informal.

Secara total pada masa periode kebijakan RPJMN-III 2014-2017, terjadi penurunan ukuran kemiskinan agregat untuk indeks kemiskinan (P0) yaitu menurun sebesar 0.6043 dari 11.2464 menjadi 10.6421, indeks kedalaman kemiskinan (P1) meningkat sebesar 0.0743 dari 1.7532 menjadi 1.8312, maupun indeks keparahan kemiskinan (P2) meningkat sebesar 0.0426 dari 0.4416 menjadi 0.4842 . Penyebab terjadinya penurunan ukuran kemiskinan agregat P0 tersebut teridentifikasi secara dominan disebabkan oleh adanya pengaruh perubahan ukuran kemiskinan pada intrasektoral dan antar-sektoral yaitu dengan persentase perubahan total pengaruh intrasektoral sebesar $68.18 \%$ dan pengaruh intra-sektoral $67.14 \%$, dan peningkatan ukuran kedalaman kemiskinan P1 dominan disebabkan oleh adanya pengaruh antar-sektoral dan pengaruh interaksi masing-masing sebesar $31.54 \%$ dan $75.13 \%$, dan peningkatan ukuran keparahan kemiskinan P2 dominan disebabkan oleh adanya pengaruh antarsektoral dan pengaruh interaksi masing-masing sebesar $41.31 \%$ dan $62.44 \%$. Walaupun secara total (agregat) indeks kemiskinannya turun akan tetapi teridentifikasi beberapa sektor yaitu sektor pertanian informal, sektor industri formal dan informal, sektor listrik formal dan informal, sektor konstruksi formal dan informal, sektor perdagangan formal, dan sektor transportasi formal dan informal besaran indeks kemiskinannya meningkat dari tahun 2014 ke tahun 2017, hal ini memberikan arti bahwa sektor-sektor tersebut tidak berhasil dalam pengentasan kemiskinan. Dan sektorsektor yang berkontribusi secara signifikan terhadap penurunan ukuran kemiskinan agregat P0 adalah sektor pertanian formal, perdagangan formal, transportasi, sektor keuangan, dan sektor lainnya. P1 dikontribusi oleh sektor pertanian formal, sektor 
pertambangan informal, sektor perdagangan formal, sektor transportasi informal, sektor keuangan formal dan informal, dan sektor lainnya. Sementara P2 dikontribusi oleh sektor pertambangan informal, sektor perdagangan formal, sektor transportasi informal, sektor keuangan formal dan informal, sektor jasa informal, dan sektor lainnya.

\subsection{Kontribusi Kemiskinan Sektoral Terhadap Agregat}

Perubahan ukuran kemiskinan dan kontribusi secara sektoral terhadap kemiskinan agregat pada setiap periode kebijakannya yaitu periode kebijakan RPJMN-I tahun 2004-2009, RPJMN-II tahun 2009-2014, dan RPJMN-III tahun 2014-2019 (dalam hal ini yang diteliti periode tahunnya adalah 2014-2017) teridentifikasi sebagai berikut:

Sektor-sektor yang berkontribusi terhadap perubahan ukuran kemiskinan agregat P0 secara signifikan terdiri atas 17 sektor pada tahun 2004 dengan pengaruh menurunkan sebanyak 16 sektor dan pengaruh meningkatkan ukuran kemiskinan sebanyak 1 sektor. Pada tahun 2009 terdiri atas 8 sektor dimana seluruhnya berpengaruh menurunkan kemiskinan P0, pada tahun 2014 terdiri atas 7 sektor dimana 4 sektor berpengaruh menurunkan dan 3 sektor berpengaruh meningkatkan ukuran kemiskinan P0, dan pada tahun 2017 terdiri atas 7 sektor dimana secara signifikan 5 sektor berpengaruh menurunkan dan 2 sektor berpengaruh meningkatkan ukuran kemiskinan P0. Sektor-sektor yang berkontribusi terhadap perubahan ukuran kedalaman kemiskinan agregat P1 secara signifikan terdiri atas 18 sektor pada tahun 2004 dimana semuanya berpengaruh menurunkan kedalaman kemiskinan P1. Pada tahun 2009 terdiri atas 10 sektor dimana sebanyak 8 sektor berpengaruh menurunkan kedalam kemiskinan P1 dan 2 sektor berpengaruh meningkatkan kedalaman kemiskinan P1, pada tahun 2014 terdiri atas 7 sektor dimana 4 sektor berpengaruh menurunkan dan 3 sektor berpengaruh meningkatkan kedalaman kemiskinan P1, dan pada tahun 2017 terdiri atas 7 sektor dimana secara signifikan 4 sektor berpengaruh menurunkan dan 3 sektor berpengaruh meningkatkan ukuran kedalaman kemiskinan P1. Sektor-sektor yang berkontribusi terhadap perubahan ukuran keparahan kemiskinan agregat P2 secara signifikan terdiri atas 15 sektor pada tahun 2004 dimana semuanya berpengaruh menurunkan keparahan kemiskinan P2. Pada tahun 2009 terdiri atas 11 sektor dimana sebanyak 10 sektor berpengaruh menurunkan keparahan kemiskinan P2 dan 1 sektor berpengaruh meningkatkan keparahan kemiskinan P2, pada tahun 2014 terdiri atas 7 sektor dimana 4 sektor berpengaruh menurunkan dan 3 sektor berpengaruh meningkatkan keparahan 
kemiskinan P2, dan pada tahun 2017 terdiri atas 5 sektor dimana secara signifikan 4 sektor berpengaruh menurunkan dan 1 sektor berpengaruh meningkatkan ukuran keparahan kemiskinan P2.

Fokus terhadap kontribusi sektor-sektor yang mengakibatkan penurunan ukuran kemiskinan agregat P0 pada tiga periode masa kebijakan pemerintah yaitu RPJMN-I, RPJMN-II, dan RPJMN-III dimana secara signifikan jumlah sektor untuk ketiga masa kebijakan tersebut adalah sama yaitu berjumlah empat sektor kegiatan pekerjaan utama dan satu sektor lainnya.

Perubahan penurunan kemiskinan agregat P0, pergeseran populasi dan persentase kontribusi pada periode kebijakan RPJMN-I tahun 2004-2009, sektor-sektor yang berpengaruh terhadap penurunan kemiskinan P0 adalah sektor pertanian informal dengan nilai perubahan sebesar minus 1.11 dengan pergeseran populasi sebesar minus 0.68 sektor ini berkontribusi menurunkan tingkat kemiskinan sebesar 3.96 persen hal ini merupakan kontribusi terbesar terhadap penurunan kemiskinan agregat P0 setelah sektor lainnya (kelompok tidak bekerja). Sektor konstruksi formal/informal dengan nilai perubahan penurunan terbesar ada pada konstruksi informal yaitu sebesar minus 4.58 dengan tanpa pergeseran populasi alias 0.00 dimana sektor ini berkontribusi menurunkan tingkat kemiskinan agregat P0 sebesar 0.74 persen. Sektor perdagangan formal/informal dengan nilai perubahan penurunan terbesar ada pada perdagangan formal yaitu sebesar minus 2.78 dengan pergeseran populasi sebesar 0.37 dan sektor ini berkontribusi terhadap penurunan kemiskinan agregat P0 sebesar 1.30 persen. Sektor transportasi formal/informal dengan nilai perubahan penurunan masing-masing adalah minus 7.09 dan minus 5.82 dengan nilai perubahan pergeseran populasi sebesar positif 0.01 dan minus 0.20 dan sektor ini berkontribusi terhadap penurunan kemiskinan agregat P0 masing-masing sebesar 1.09 dan 1.49 persen.

Perubahan penurunan kemiskinan agregat $\mathrm{P} 0$, pergeseran populasi dan persentase kontribusi pada periode kebijakan RPJMN-II tahun 2009-2014, sektorsektor yang berpengaruh terhadap penurunan kemiskinan P0 adalah sektor pertanian formal dengan nilai perubahan sebesar minus 4.42 dengan pergeseran populasi sebesar positif 0.35 , sektor ini berkontribusi menurunkan tingkat kemiskinan sebesar 3.13 persen hal ini merupakan kontribusi terbesar terhadap penurunan kemiskinan agregat P0 setelah sektor lainnya (kelompok tidak bekerja). Sektor perdagangan formal dengan 
nilai perubahan peningkatan sebesar positif 1.67 dengan pergeseran populasi sebesar 0.93, sektor ini berkontribusi menurunkan tingkat kemiskinan agregat P0 sebesar minus 0.88 persen. Sektor transformasi formal/informal dengan nilai perubahan peningkatan ukuran kemiskinan agregat P0 masing-masing sebesar positif 5.35 formal dan positif 5.52 informal dengan perubahan pergeseran populasi masing-masing sebesar 0.42 dan 0.62 dimana sektor-sektor ini berkontribusi terhadap penurunan kemiskinan agregat P0 masing-masing sebesar minus 0.22 persen dan minus 0.91. Sektor keuangan formal/informal dengan nilai perubahan penurunan masing-masing adalah minus 7.24 dan minus 4.45 dengan nilai perubahan pergeseran populasi sebesar positif 0.09 dan positif 0.11 dan sektor ini berkontribusi terhadap penurunan kemiskinan agregat P0 masing-masing sebesar 0.77 dan 1.73 persen.

Perubahan penurunan kemiskinan agregat $\mathrm{P} 0$, pergeseran populasi dan persentase kontribusi pada periode kebijakan RPJMN-III tahun 2014-2017, sektorsektor yang berpengaruh terhadap penurunan kemiskinan P0 adalah sektor pertanian informal dengan nilai perubahan sebesar positif 1.13 berpengaruh meningkatkan kemiskinan agregat $\mathrm{P} 0$, dimana perubahan pergeseran populasi sebesar positif 6.85 sektor ini berkontribusi menurunkan tingkat kemiskinan sebesar minus 4.87 persen hal ini merupakan kontribusi terbesar terhadap penurunan kemiskinan agregat P0 setelah sektor lainnya (kelompok tidak bekerja). Sektor perdagangan formal dengan nilai perubahan penurunan sebesar minus 0.09 dengan perubahan pergeseran populasi sebesar positif 0.93 dimana sektor ini berkontribusi menurunkan tingkat kemiskinan agregat P0 sebesar minus 0.89 persen. Sektor transportasi formal/informal dengan nilai perubahan penurunan masing-masing sebesar minus 1.45 dan minus 0.36 dengan perubahan pergeseran populasi masing-masing sebesar 0.42 dan 0.62 dan sektor ini berkontribusi menurunkan tingkat kemiskinan agregat P0 sebesar minus 2.70 persen dan minus 0.23 persen. Sektor keuangan formal/informal dimana sektor formal berpengaruh meningkatkan kemiskinan agregat P0 dengan nilai perubahannya sebesar 0.08 sedangkan sektor informalnya berpengaruh menurunkan kemiskinan agregat dengan nilai perubahannya sebesar minus 2.04 , dan perubahn pergeseran populasinya masingmasing sebesar 0.09 untuk sektor keuangan formal dan 0.11 untuk sektor keuangan informal dengan persentase kontribusi terhadap penurunan kemiskinan agregat P0 masing-masing sebesar 3.66 persen dan 5.05 persen. 


\section{KESIMPULAN DAN REKOMENDASI}

\subsection{Kesimpulan}

1. Secara agregat terjadi penurunan ukuran kemiskinan baik untuk indeks kemiskinan P0, indeks kedalaman kemiskinan P1, maupun indeks keparahan kemiskinan P2 pada periode masa kebijakan RPJMN-I 2004-2009 dan RPJMN-II 2009-2014, sedangkan pada periode kebijakan RPJMN-III 2014-2017 penurunan terjadi hanya pada kemiskinan P0 akan tetapi kedalaman kemiskinan P1 dan keparahan kemiskinan P2 mengalami peningkatan dimana peningkatannya dominan dipengaruhi oleh interaksi antara pengaruh intra-sektor dan antar-sektor dengan persentase kontribusi perubahannya sebesar 75.13 persen untuk kedalaman kemiskinan P1 dan sebesar 62.44 persen untuk keparahan kemiskinan P2. Pada masa RPJMN-I penurunan kemiskinan P0 dominan dipengaruhi oleh pengaruh intra-sektoral dimana penurunan kemiskinan P0, kedalaman kemiskinan P1, dan keparahan kemiskinan P2 masing-masing persentase kontirbusinya adalah sebesar 85.16 persen, 87.39 persen dan 90.88 persen. Dan Pada masa RPJMN-II juga penurunan kemiskinan P0 dominan dipengaruhi oleh pengaruh intra-sektoral dimana penurunan kemiskinan P0, kedalaman kemiskinan P1, dan keparahan kemiskinan P2 masing-masing persentase kontirbusinya adalah sebesar 58.75 persen, 68.07 persen dan 68.60 persen.

2. Berdasarkan sektoral penurunan tingkat kemiskinan agregat P0 pada tiga periode masa kebijakan secara signifikan dikontribusi oleh lima sektor lapangan pekerjaan utama yaitu pada RPJMN-I oleh sektor pertanian informal, sektor konstruksi formal/informal, sektor perdagangan formal/informal, sektor transportasi formal/informal, dan sektor lainnya. pada RPJMN-II dikontribusi oleh sektor pertanian formal, sektor perdagangan formal, sektor transportasi formal/informal, sektor keuangan formal/informal, dan sektor lainnya. Dan pada RPJMN-III secara signifikan dikotribusi oleh sektor pertanian informal, sektor perdagangan formal, sektor transportasi formal/informal, sektor keuangan formal/informal, dan lainnya.

3. Perubahan tingkat kedalaman kemiskinan agregat $\mathrm{P} 1$ dan keparahan kemiskinan $\mathrm{P} 2$ pada RPJMN-I dan RPJMN-II perubahannya adalah penurunan dimana masingmasing secara sektoral dikontribusi oleh 7 sektor untuk P1 dan 9 sektor untuk P2 pada RPJMN-I, dan 6 sektor untuk P1 dan 6 sektor untuk P2 pada RPJMN-II, 
sedangkan pada RPJMN-III perubahannya adalah peningkatan baik untuk kedalaman kemiskinan P1maupun keparahan kemiskinan P2 dimana jumlah sector yang berkontribusinya masing-masing adalah 6 sektor untuk P1 dan 4 sektor untuk P2.

\subsection{Rekomendasi}

Berdasarkan hasil dari analisis dekomposisi sektoral yang diperoleh, terlihat bahwa besaran ukuran kemiskinan secara agregat pada dasarnya sangat dipengaruhi oleh perubahan ukuran kemiskinan mikronya dalam hal ini sektor lapangan pekerjaan utama, maka "Angka Ukuran Kemiskinan Sektoral” yang diperoleh adalah merupakan sinyal atau tanda bagi Sektor (Departemen/K/L) yang berkaitan, dimana dapat digunakan sebagai tindakan didalam melakukan perbaikan (perencanaan program) kedepan. Untuk itu sebagai saran kebijakan diharapkan:

1. Bila Kebijakan pertumbuhan ekonomi yang diambil/dijalankan demi untuk menekan tingkat kemiskinan hendaklah dikenakan kepada sektor perekonomian secara langsung (sektoral) yaitu sektor-sektor yang banyak menyerap tenaga kerja antara lain adalah sektor pertanian, sektor industri, sektor perdagangan, sektor transportasi, dan sektor jasa.

2. Lembaga atau Badan berwenang di Indonesia (BPS utamanya) agar dapat melakukan dan menyediakan data survey susenas yang bisa digunakan untuk analisis kemiskinan sampai level sektor kegiatan ekonomi (sektor lapangan pekerjaan utama), mengingat data survey susenas yang ada sekarang masih kurang ketersediaanya bagi peruntukan analisis kemiskinan pada level ini.

Analisis dekomposisi kemiskinan ini bisa digunakan atau diterapkan juga untuk fokus atau tujuan dekomposisi secara sektoral lainnya, dengan demikian yang dilakukan disini adalah hanya merupakan salah satu aplikasi analisis dekomposisi kemiskinan yang diterapkan terhadap sektor lapangan pekerjaan utama.

\section{DAFTAR PUSTAKA}

Badan Pusat Statistik (2004, 2009, 2014, 2017), Survey Sosial Ekonomi Nasional tingkat rumah tangga (Susenas-2004, Susenas-2009, Susenas-2014, Susenas2017), BPS, Jakarta. 
Bank Dunia (Maret 2017), Perkembangan Tri-wulanan Perekonomian Indonesia: Melanjutkan Perubahan, The WorldBank, Jakarta.

Datt, Gaurav (October 1998); Computational Tools for Poverty Measurement and Analysis, Food Consumption and Nutrition Division, International Food Policy Research Institute, Washington D.C.

Friedman, Jed (August 2003); "How Responsive is Poverty to Growth: A Regional Analysis of Poverty, Inequality, and Growth in Indonesia, 1984-99”, World Institute for Development Economics Research, United Nations University, Discussion Paper No.2003/57.

Foster, J., J. Greer \& E. Thorbecke (1984) “A Class of Decomposable Poverty Measures", Econometrica 52(3):761-6.

Huppi, Monika, \& Ravallion, Martin (1990); “The Sectoral Structure of Poverty During an Adjusment Period: Evidence for Indonesia in the Mid-1980s", The World Bank, Washington D.C.

Kakwani, Nanak (December 1992); "Statistical Inference in the Measurement of Poverty”, The University of New South Wales, New South Wales.

Kakwani, Nanak (January 1990); “Testing for Significance of Poverty Differences with Application to Cote d'Ivoire”, Living Standards Measurement Study, Working Paper No.62 of the World Bank.

Ravallion, Martin (February 1992); "Poverty Comparisons: A Guide to Concepts and Methods", The World Bank Working paper, Washington D.C.

Ravallion, Martin, \& Huppi, Monika (Januari 1991); "Measuring Changes in Poverty: A Methodological Case Study of Indonesia during an Adjusment Period", The World Bank, Washington D.C.

Suselo, Sri Liliani, \& Tarsidin (Oktober 2008); “Kemiskinan di Indonesia: Pengaruh Pertumbuhan dan Perubahan Struktur Ekonomi”, Pusat Pendidikan dan Studi Kebanksentralan, Bank Indonesia, Jakarta.

Sen, A. (1979); "Issues in the Measurement of Poverty", Scandinavia Journal of Economics, Vol. 81, pp 285-307. 